\title{
The Impact of Study Abroad on Academic Success: An Analysis of First-Time Students Entering Old Dominion University, Virginia, 2000-2004
}

Min Xu

Old Dominion University

Chandra R. de Silva

Old Dominion University

Ellen Neufeldt

Old Dominion University

Jane H. Dane

Old Dominion University

\section{Introduction}

There is a widespread assumption that study abroad develops skills that are marketable in an increasingly global market. A recent study suggested that nearly $85 \%$ of 1008 students who participated in study abroad programs between 2006 and 2011 felt that this experience helped them to build job skills (Preston, 2012). However, one of the top concerns about or perceived obstacles to studying abroad is whether "studying abroad will delay graduation," especially if such programs are undertaken early in a student's college life. Research studies reveal that up to $46 \%$ of all students (more male than female) feared that participation in study abroad might delay their graduation (Kasravi, 2009; Shirley, 2006; Toncar, Reid, \& Anderson, 2005). Students at many institutions, including Old Dominion University (ODU), have undertaken study abroad mostly after their sophomore year, well after they have chosen a major. The profile of U.S. students studying abroad compiled by the Institute of International Education indicates that between 2000 and 2011, junior and senior students accounted for $54-61 \%$ of all students who studied abroad (including graduate students) (IIE, 2012).

An investigation of the benefits of study abroad in terms of time to graduation is important also because participation in study abroad has opportunity costs. For students on financial aid through federal dollars (Pell Grants), time to degree is an important factor because there is a six-year eligibility limit on Pell Grants. Students from low and middle income households have to forego part or all of their summer earnings if they go abroad in the summer and also obtain extra funding 
for costs of travel and lodging. At many public universities, a semester-long study abroad program entails substantial extra costs in terms of airfare and lodging.

The present study was designed to investigate whether semester-long study abroad has had a positive effect on degree attainment of undergraduate students at Old Dominion University and if so, to see if we could identify time in a student's career when such participation would have an optimal impact.

\section{Review of Literature}

Since the 1970s, significant research has explored the results and impacts of study abroad relating to individual development, the host and home institutions, and inter-societal and international relations (Flack, 1976). Although most previous research has focused on developmental aspects of study abroad, such as language learning, personal growth, intercultural awareness, and professional development (Doyle, 2009; Hadis, 2005; Ingraham \& Peterson, Fall 2004), more recent research has also focused on the impact of study abroad on academic outcomes, such as degree attainment, partly because outcomes are increasingly seen as a measure of the success of an institution (Barclay Hamir, 2011).

There have been a number of studies on the impact of study abroad on graduation rates. For example, the Office of Institutional Research at the University of Minnesota-Twin Cities provides descriptive statistics on their website regarding graduation rates of students entering 1999-2002. Their data show that in respect of the fall 2003 freshman cohort, 64.5\% of study abroad participants graduated in four years, as compared to 41 percent of nonparticipants. At the five-year mark, the graduation figure increased to $90 \%$ for participants, and $58.6 \%$ for nonparticipants (Office of Institutional Research, April 2009). At the University of California, San Diego, five year graduation rates of the fall 2002 cohort were calculated at $92 \%$ for study abroad participants, and $78 \%$ for nonparticipants (Student Research and Information, 2009). However, these figures do not take into account other variables, including previous academic achievement. Therefore, questions remain as to whether these figures represented the positive effect of study abroad or were due to other differences between study abroad participants and nonparticipants.

A study at Indiana University, Bloomington, where researchers controlled for academic achievement, area of study, and socioeconomic and demographic background of seven cohorts 20012007 indicates that those who had participated in study abroad at that institution had a fifth year graduation rate of $91 \%$ as against $84 \%$ for nonparticipants (University Planning, May 2009). There are many other studies relating to the impact of study abroad. One recent major study compared 19,109 study abroad students on all public campuses of the state of Georgia (including community colleges) with a control group of 17,903 . This study found that the four-year graduation rate was $49.6 \%$ for study abroad students, compared to $42.1 \%$ for students in the control group (and 24 percent for all students in the system). Five-year graduation rates were $82.6 \%$ for study abroad participants and $74.7 \%$ for students in the control group. Six-year rates were $88.7 \%$ for study abroad participants and $83.4 \%$ for students in the control group. However, only the fifth year graduation rate manifests a statistically significant effect of study abroad (O'Rear, Sutton, \& Rubin, 2012). 
Metzger (2006) argued that study abroad was an effective retention strategy particularly for minority students. This is also supported by the work of Heather Barclay Hamir in her Ph.D. dissertation of 2011. Her results indicate that study abroad participants graduated at a higher rate and graduated in a slightly shorter period of time (Barclay Hamir, 2011). However, the Indiana study quoted above concludes that "although overseas study may give underrepresented minorities a boost to graduate within four years versus return for a fifth year of study, their participation in overseas study does not appear to reduce their chances of departing without a degree." (University Planning, May 2009, p.13).

To summarize, recent research on the impact of study abroad has suggested a positive impact of study abroad on timely degree attainment. However, the scarcity of quantitative assessments of the impact of study abroad on academic outcomes, some inconsistencies in statistical methodologies used, the use of different sets of variables, and mixed, though promising, results suggest the need for additional research in this area. As such, this study is designed to use a sample of students from Old Dominion University to find out whether semester-long study abroad has had a positive effect on degree attainment of undergraduate students after statistically adjusting for other relevant factors of degree attainment, such as demographics and prior academic achievement.

\section{Methodology}

\section{Sample}

The sample consists of two groups of students (106 freshmen who had studied abroad for a semester and 6346 freshmen who had not participated in such study abroad programs) and was selected through two steps. As the first step, we identified students who had participated in semesterlong study abroad programs between fall 2003 and fall 2006 and who were first-time degree-seeking freshmen at Old Dominion University. The start date was governed by the fact that Old Dominion University's database had reliable data for our purposes only after summer 1999. Students who studied abroad after summer 2006 were not selected to exclude those who might matriculate too late for us to observe their six-year graduation rates. This led to a sub-sample of 106 students who had studied abroad. In the second step, the study abroad student sample was matched with their domestic peers: freshmen from the same entering cohorts who had never studied abroad (the domestic group). Because students at Old Dominion University usually study abroad during their junior, senior, or sophomore years, records of students who did not persist beyond their sophomore year (second year) were filtered out. After filtering, data cleaning, and excluding records that have missing values on key variables of interest, the result was a sample of 6,452 freshman students who entered between fall 2000 and fall 2004, including 106 freshmen who had studied abroad for a semester and 6,346 freshmen who had not participated in such study abroad programs.

\section{Statistical Analysis}

Data were collected through the university's central database. The variables include three response variables (i.e., four-, five-, and six-year graduation) and six explanatory variables (predictors or factors): High School GPA, First-Year GPA, Gender, Race, Studying Abroad, and the SAT score (The SAT score was excluded from the final analysis due to its insignificance in predicting graduation). 
To study the impact of study abroad on undergraduate degree completion, the academic performance of the two groups was first compared in terms of four-, five-, and six-year graduation rates as well as cumulative GPA and credit hours earned at the end of fourth, fifth, and sixth year. Next, because the responsible variable (graduation) is dichotomous, with two response levels (either graduated or not graduated), a logistic regression analysis was conducted to study the possible effect of studying abroad on graduation after controlling for demographics and prior academic achievement factors as detailed above.

\section{Results}

As the first step of analysis, the academic performance of the two groups in the sample (the study-abroad group and the domestic group) was compared (See Table 1). As shown in Table 1, the four-, five-, and six-year graduation rates of the study-abroad group surpassed those of the domestic group by $18 \%, 24 \%$, and $23 \%$, respectively. The study-abroad group also took more credit hours and had a higher average college GPA than the domestic group. To identify factors that might explain the better academic performance of the study abroad students, it was decided to compile statistics on prior academic achievement (high school GPA and first-year GPA) and academic aptitude (SAT score, the combined verbal and mathematics SAT scores) of the two groups. These are also displayed in Table 1. As shown in Table 1, the study abroad students achieved higher high school GPAs, SAT scores, and first-year GPAs than their domestic peers. Therefore, a legitimate and important research question is whether the better academic performance of the study abroad students, such as the better graduation rates, is related to studying abroad or simply an impact of demographics and better academic achievement prior to studying abroad. The logistic regression which follows addresses the question whether the likelihood that a freshman student graduating is related to studying abroad after controlling for demographics and academic achievement factors.

\section{Logistic Regression Results}

Three five-predictor logistic models were fitted to the data to answer the research question regarding the relationship between the likelihood of a freshman student graduating in four, five, and six years and the five factors: High School GPA, First-Year GPA, Gender, Race, and Studying Abroad. The SAT score was dropped from the final models due to its insignificance in predicting graduation. A description of the factors included in the logistic regression is displayed in Table 2. The logistic regression analysis was carried out using SAS 9.2.

The first logistic regression model tested the relationship between four-year graduation and the five factors. The results of this model are displayed in Table 3. As shown in Table 3, the log of the odds of a freshman to graduate within four years was not related to studying abroad, but was related to the other four factors: High School GPA, First-Year GPA, Gender, and Race. According to this model, the higher the high school GPA and first year GPA, it was more likely that a freshman student would graduate within four years. For a 1 point increase in high school GPA, the odds of graduating in four years were 1.531 times greater. For a 1 point increase in first-year GPA, the odds of graduating in four years were 4.853 times greater. Also, the odds of graduating in four years for females were 1.61 times greater than the odds for males; and the odds of graduating in four years for being African American were 1.282 times greater than the odds for being white. 
The second logistic regression model tested the relationship between five-year graduation and the five factors. The results of this model are displayed in Table 4. As shown in Table 4, the log of the odds of a freshman graduating within five years was related to all the five factors. Therefore, studying abroad is a statistically significant predictor of five-year graduation after controlling for the other four factors. According to this model, the higher the high school GPA and first year GPA, it is more likely that a freshman student would be graduating within five years. For a 1 point increase in high school GPA, the odds of graduating in five years were 1.573 times greater. For a 1 point increase in first-year GPA, the odds of graduating in five years were 3.745 times greater. Also, the odds of graduating in five years for females were 1.251 times greater than the odds for males; the odds of graduating in five years for being African American were 1.241 times greater than the odds for being white; and the odds of graduating in five years for the study abroad students were 1.877 times greater than the odds for their domestic peer group.

The third logistic regression model tested the relationship between six-year graduation and the five factors. The results of this model are displayed in Table 5. As shown in Table 5, the log of the odds of a freshman to graduate within six years was again related to all five factors, including study abroad. According to this model, the higher the high school GPA and first year GPA, it is more likely that a freshman student would be graduating within six years. For a 1 point increase in high school GPA, the odds of graduating in six years were 1.477 times greater. For a 1 point increase in first-year GPA, the odds of graduating in six years were 3.638 times greater. Also, the odds of graduating in six years for females were 1.228 times greater than the odds for males; the odds of graduating in six years for African American students were 1.179 times greater than the odds for white students; and the odds of graduating in six years for students participating in study abroad programs were 2.03 times greater than the odds for their domestic peer group.

A comparison of the results of the three models suggest that, while studying abroad for a semester was not a statistically significant predictor for four-year graduation, it has significance in predicting five- and six-year graduation, and that other factors become less significant in predicting five- and six-year graduation. The reason why study abroad affects five year and six year graduation rates but is not significant for four year graduation rates may be due to the fact that most ODU students studied abroad for a semester during junior and senior years. Among the subsample of study abroad participants at ODU, 79.25\% were juniors and seniors. Thus, study abroad participation came too late in a student's academic career to impact four-year graduation.

Our results on the impact of semester-long study abroad on four year graduation rates is consistent with the major studies using data from University System of Georgia (GLOSSARI Project), which found that study abroad manifests a statistically significant effect only on the likelihood of graduating within five years (O'Rear, et al., 2012; Sutton \& Rubin, 2010). Our results of the significant relationships of study abroad to the likelihood of graduating in five and six years, together with the composition of our study abroad group ( $79.25 \%$ were juniors and seniors), help better explain the beneficial impact of study abroad on degree attainment in all years concerned: that is why semester-long study abroad was not a statistically significant predictor for graduating in four years, but a significant predictor for graduating in five and six years. 


\section{Discussion}

The significant relationships between studying abroad and five- and six-year graduation in this analysis suggest the beneficial effects of study abroad programs on undergraduate degree completion. Currently, most students at ODU wait until their junior year to participate in study abroad programs. This may not allow sufficient time for an impact on four-year graduation. Old Dominion University might be able to increase its four-year graduation rate by encouraging students to choose to study abroad earlier (at least in the sophomore year) during their college careers. This conclusion is supported by the research conducted by Heather Barclay Hamir at the University of Texas (Barclay Hamir, 2011). Other universities, including Michigan State University, send freshmen students on short-term (two-week) study abroad programs before they enroll for classes; Acadia University has had such programs from 1994 and, since 2003, has begun a semester-abroad program for freshmen (Wilhelm, September 3, 2012).

The data analyzed above also suggest that Old Dominion University might be able to improve its five and six year graduation rates by simply encouraging more students to participate in semesterlong study abroad programs and providing more support for students. The improvement in graduation rates could be because those participating in study acquire better applied knowledge as suggested from a three-case study analysis in the GLOSSARI Project (Sutton \& Rubin, 2010). Our results provide empirical evidence for using study abroad as an retention tool/strategy, as also indicated by other researchers (Barclay Hamir, 2011; Metzger, 2006).

In the last few years the funds allotted to support study abroad at Old Dominion University have expanded with academic colleges contributing towards study-abroad scholarships. The total numbers of those who participate in short study abroad programs have also risen in the last few years. However, the total number of Old Dominion University students who participate in semesterlong study abroad programs in any one year is still well under 100 (out of a total student enrollment of 25,000). Even if we include short-term study abroad programs, the total annual participation is still less than 300. A more aggressive approach to expansion of study abroad programs and marketing them to students might yield substantial dividends.

According to the results of the 2012 National Survey of Student Engagement (NSSE) for Old Dominion University, 35\% of freshmen respondents planned on doing study abroad (Old Dominion University, 2012). This was identical to the NSSE 2010 survey figure although higher than the 2006 response which was that $29 \%$ had that intention. On the other hand, the 2012 NSSE survey of seniors indicated that only $5 \%$ had actually participated in study abroad. The participation rates reported by seniors were 5\% in 2010 and $8 \%$ in 2006. In comparable Carnegie Research Universities, the first-year aspiration to study abroad was $42 \%$ in 2012 and the senior class of that year reported a completion rate of $13 \%$. The corresponding figures in those institutions for 2010 were $44 \%$ and $13 \%$ and for $2006,32 \%$ and $8 \%$. This indicated a significant and continuing gap between aspirations and achievement among ODU students in respect of study abroad. Old Dominion University seniors include a much higher proportion of transfers than at other institutions in its Carnegie class. Therefore, we also analyzed the gap between aspiration rates freshmen students who were not transfers (36\% in both 2012 and 2010) and completion rates for seniors who were not transfers (6.5\% in 2012 and $7.3 \%$ in 2010). These statistics reinforced our 
conclusion that Old Dominion University is falling further behind as years go by (Old Dominion University, 2012).

Meanwhile the importance of study abroad has received increasing national recognition. A February 2012 Report on Graduation rates at the University of Texas at Austin identified study abroad, together with undergraduate research and service learning as an "academic enrichment experience” (Diehl, 2012, p. 14). The University of San Diego has also made study abroad an important part of its retention strategy (Redden, July 10, 2012).

Our data did not allow us to compare the impact of short-term and long-term study abroad programs on graduation. However, Barclay Hamir's research seems to indicate that "increased degree completion rates occurred regardless of the type or length of program in which students participated" (Barclay Hamir, 2011, p.179). Another area of investigation that this study could not address is whether or not the benefits associated with participation in study abroad also apply equally to non-credit bearing international activities. Old Dominion University has some non-credit bearing "study away" opportunities (involving study at locations away from Hampton Roads but within the United States). Given the rapid expansion of student experiences outside the location of the institution and the inability of some students to go on study abroad programs due to a variety of reasons, it might be useful to investigate how less traditional options might be utilized to benefit students. The University of Georgia Glossari Project which documents learning outcomes might provide some leads on how this might be done (Sutton \& Rubin, 2010). Barclay Hamir suggests that it is possible that part of the shorter time-to-degree "occurs because study abroad participants engage in an extra level of academic planning to graduate" (Barclay Hamir, 2011, p. 182). If this is valid, non-credit 'study away' programs might help to develop some of the learning outcomes that arise from study-abroad programs especially if they are well-planned.

The GPA requirement ( $>=2.0$ ) of our study abroad participants did not allow us to make meaningful inferences about the impact of study abroad on students with low GPAs, and this could be an area for further study. Also, our data did not allow for significant conclusions about differential benefits acquired by African Americans because the number of African Americans who participated in study abroad was small. However, a study at the University of Georgia found that four-year graduation rates were 13-31\% higher for African Americans who studied abroad when compared to a control group, and 7-18\% higher for other nonwhite students (Sutton \& Rubin, 2010). Further statistical analysis may need to be performed to confirm this potential differential benefits to the African American participants.

\section{Practical Recommendations for Improving Study Abroad and Student Success}

Based on our results of study, the following recommendations are proposed for improving study abroad and student success at ODU and other institutions with low study abroad participation rates:

\section{To expand study abroad programs}

The beneficial effect of study abroad on improving undergraduate retention and degree completion as suggested by our analysis indicates that universities should devote more attention to the expansion of study abroad opportunities. One way to expand study abroad programs is to design study abroad programs appropriate for sophomore and first year students. Our results suggest that encouraging students to study abroad earlier in their college career, such as in the sophomore year, 
may help improve the four-year graduation rate. Nationally dozens of universities are offering opportunities for students to study abroad early in their college life. The two successful examples are Michigan State University and Arcadia University, which have well-established first-year study abroad programs (Wilhelm, September 3, 2012). Such successful examples may help us address challenges involved when designing study abroad programs specifically for first-year students.

To reduce the gap between aspirations and actual participation in study abroad programs

The gap between the two groups of students as suggested by NSSE data indicates possible barriers preventing them from study abroad. This may include academic barriers, such as needing more information on study abroad early in college, the perception that study abroad may distract them from timely graduation, and financial barriers, such as lack of scholarship funding or programing at different price points (Barclay Hamir, 2011). Early promotion of study abroad opportunities with admissions staff and advocacy of study abroad in programs for prospective and admitted students might help to reduce the gap between aspiration and actual participation.

\section{Collaboration between divisions}

Even though our results and previous research suggest that study abroad may well be a retention strategy for improving retention and success of undergraduate students, the benefits of study abroad would not occur automatically. Rather, the challenges in achieving a transformative study abroad experience require a collaborative endeavor among academics, student affairs staff and study abroad professionals. We need to help students with effective academic planning and prepare them for other facets of study abroad, such as issues with health, safety, and even crime and political concerns (Rhodes, Biscarra, Loberg, \& Roller, 2012).

\section{References}

Barclay Hamir, H. (2011). Go Abroad and Graduate On-Time: Study Abroad Participation, Degree Completion, and Time-to-Degree. Ph.D. Dissertation, University of Nebraska - Lincoln.

Retrieved from http://world.utexas.edu/forms/abroad/barclay-dissertation.pdf

Doyle, D. (2009). Holistic Assessment and the Study Abroad Experience. Frontiers: The Interdisciplinary Journal of Study Abroad, 18, 143-155.

Flack, M. J. (1976). Results and Effects of Study Abroad. The ANNALS of the American Academy of Political and Social Science, 424, 107-117.

Hadis, B. F. (2005). Why Are They Better Students when They Come Back? Determinants of Academic Focusing Gains in the Study Abroad Experience. Frontiers: The Interdisciplinary Journal of Study Abroad, 11, 57-70.

IIE. (2012). Profile of U.S. Study Abroad Students, 2000/01-2010/11, Open Doors Report on International Educational Exchange. Retrieved from http://www.iie.org/en/Research-andPublications/Open-Doors/Data/US-Study-Abroad/Student-Profile/2000-11

Ingraham, E. C., \& Peterson, D. L. (Fall 2004). Assessing the Impact of Study Abroad on Student Learning at Michigan State University. Frontiers: The Interdisciplinary Journal of Study Abroad, 10, 83-100. 
Kasravi, J. (2009). Factors Influencing the Decision to Study Abroad for Students of Color: Moving Beyond the Barriers. Doctoral dissertation, University of Minnesota-Twin Cities, Minneapolis, MN. Retrieved from http://conservancy.umn.edu/bitstream/55058/1/Kasravi_umn_0130E_10602.pdf

Metzger, C. A. (2006). Study Abroad Programming: A 21st Century Retention Strategy? College Student Affairs Journal, 25(2), 164-175.

Old Dominion University (2012). National Survey of Student Engagement: Institutional Report for Old Dominion University, Norfolk, VA: Old Dominion University. Available for restricted access at the Office of Assessment, Old Dominion University.

Office of Institutional Research, University of Minnesota. (April 2009). Study Abroad Does Not Delay Graduation, Retrieved from http://www.umabroad.umn.edu/assets/files/PDFs/ci/Evaluation\%20Pages/GraduationRatesUMTC.pdf

O’Rear, I., Sutton, R. L., \& Rubin, D. L. (2012). The Effect of Study Abroad on College Completion in a State University System. Retrieved from http://glossari.uga.edu/wpcontent/uploads/downloads/2012/01/GLOSSARI-Grad-Rate-Logistic-Regressions-040111.pdf.

Preston, K. (2012). Recent Graduates Survey: The Impact of Studying Abroad on Recent College Graduates' Careers, 2006-2011. Retrieved from https://www.iesabroad.org/IES/permalink/6875bcbc-b964-11e1-82f3-dfb2b24b2427.pdf

Redden, E. (July 10, 2012). Study Abroad, Graduate on Time, Inside Higher Ed. Retrieved from http://www.insidehighered.com/news/2012/07/10/new-studies-link-study-abroad-time-graduation

Rhodes, G., Biscarra, A., Loberg, L., \& Roller, K. (2012). Study Abroad as a Collaborative Endeavor. About Campus, 16(6), 2-10.

Shirley, S. W. (2006). The Gender Gap in Post-secondary Study Abroad: Understanding and Marketing to Male students., Doctoral dissertation, University of North Dakota, Grand Forks. Retrieved from http://www.departments.dsu.eduldeanofstudents/steveshirleydissertation.pdf

Student Research and Information, S. A. (2009). Retention, Graduation, \& Time-to-Degree:First Time Freshmen, Retrieved from http://icenter.ucsd.edu/_files/icenter/0809EAP_OAPcombined.pdf Sutton, R. C., \& Rubin, D. L. (2010). Documenting the Academic Impact of Study Abroad: Final Report of the GLOSSARI Project. Paper presented at the NAFSA Annual Conference, Kansas City, Missouri. Retrieved from http://glossari.uga.eduldatasets/pdfs/FINAL.pdf

Toncar, M. F., Reid, J. S., \& Anderson, C. E. (2005). Perceptions and Preferences of Study Abroad: Do Business Students Have Different Needs? Journal of Teaching in International Business, 17(1/2), 61-80.

University Planning, I. R., and Accountability. (May 2009). Plans, Participation, and Outcomes: Overseas Study at Indiana University Bloomington. Retrieved from http://www.iu.edu/-uirr/reports/special/doc/Overseas\%20Study\%20-\%20Report.pdf

Wilhelm, I. (September 3, 2012). For a Growing Number of Freshmen, Packing for College Requires a Passport, The Chronicle of Higher Education. Retrieved from http://chronicle.com/article/For-a-Growing-Number-of/134092/ 
Table 1 Academic Performance of the Study Abroad Students and Their Domestic Peers

\begin{tabular}{|c|c|c|c|c|c|c|c|c|c|c|c|c|c|}
\hline \multirow{3}{*}{ Group } & \multirow{3}{*}{$\begin{array}{l}\text { Total } \\
\text { Sample }\end{array}$} & \multirow{2}{*}{\multicolumn{3}{|c|}{ Graduation Rate }} & \multirow{2}{*}{\multicolumn{3}{|c|}{$\begin{array}{l}\text { GPA Hours by the } \\
\text { End of }\end{array}$}} & \multirow{2}{*}{\multicolumn{3}{|c|}{$\begin{array}{l}\text { Cumulative GPA at } \\
\text { the End of }\end{array}$}} & \multirow{2}{*}{\multicolumn{3}{|c|}{$\begin{array}{l}\text { Prior Ac } \\
\text { Achievement } \\
\text { Aptitude }\end{array}$}} \\
\hline & & & & & & & & & & & & & \\
\hline & & $\begin{array}{l}\text { 4- } \\
\text { Year }\end{array}$ & $\begin{array}{l}5- \\
\text { Year }\end{array}$ & $\begin{array}{l}\text { 6- } \\
\text { Year }\end{array}$ & $\begin{array}{l}\text { 4- } \\
\text { Year }\end{array}$ & $\begin{array}{l}5- \\
\text { Year }\end{array}$ & $\begin{array}{l}\text { 6- } \\
\text { Year }\end{array}$ & $\begin{array}{l}\text { 4- } \\
\text { Year }\end{array}$ & $\begin{array}{l}5- \\
\text { Year }\end{array}$ & $\begin{array}{l}\text { 6- } \\
\text { Year }\end{array}$ & $\begin{array}{l}\text { High } \\
\text { School } \\
\text { GPA }\end{array}$ & SAT & $\begin{array}{l}\text { First- } \\
\text { Year } \\
\text { GPA }\end{array}$ \\
\hline $\begin{array}{l}\text { Study- } \\
\text { Abroad }\end{array}$ & 106 & $46 \%$ & $77 \%$ & $84 \%$ & 100 & 108 & 110 & 3.24 & 3.23 & 3.23 & 3.37 & 1123 & 3.27 \\
\hline Domestic & 6346 & $28 \%$ & $53 \%$ & $61 \%$ & 93 & 102 & 105 & 2.70 & 2.70 & 2.71 & 3.21 & 1041 & 2.81 \\
\hline
\end{tabular}


Table 2 Description of Key Factors for Logistic Regression

\begin{tabular}{|c|c|c|c|c|c|c|c|}
\hline \multirow[b]{2}{*}{ Gender } & \multirow[b]{2}{*}{ Race } & \multirow{2}{*}{$\begin{array}{l}\text { Study } \\
\text { Abroad }\end{array}$} & \multirow{2}{*}{$\begin{array}{l}\text { Total } \\
\text { Sample }\end{array}$} & \multicolumn{2}{|c|}{ High School GPA } & \multicolumn{2}{|c|}{ First Year GPA } \\
\hline & & & & Mean & SD & Mean & SD \\
\hline \multirow{10}{*}{ Male } & \multirow{2}{*}{ Unknown } & Yes & 1 & 3.42 & . & 2.76 & . \\
\hline & & NO & 132 & 3.15 & 0.43 & 2.78 & 0.65 \\
\hline & \multirow{2}{*}{ BLK } & Yes & 1 & 2.72 & . & 3.45 & . \\
\hline & & NO & 519 & 3.09 & 0.4 & 2.55 & 0.68 \\
\hline & AMI & NO & 20 & 3.11 & 0.38 & 2.68 & 0.56 \\
\hline & ASI & NO & 229 & 3.2 & 0.45 & 2.75 & 0.7 \\
\hline & \multirow{2}{*}{ HIS } & Yes & 2 & 2.95 & 0.1 & 3.09 & 0.29 \\
\hline & & NO & 85 & 3.02 & 0.43 & 2.58 & 0.82 \\
\hline & \multirow{2}{*}{ WHI } & Yes & 24 & 3.25 & 0.32 & 3.18 & 0.39 \\
\hline & & NO & 1731 & 3.17 & 0.44 & 2.76 & 0.71 \\
\hline \multirow{12}{*}{ Female } & \multirow{2}{*}{ Unknown } & Yes & 6 & 3.63 & 0.34 & 3.49 & 0.28 \\
\hline & & NO & 108 & 3.25 & 0.46 & 2.93 & 0.69 \\
\hline & \multirow{2}{*}{ BLK } & Yes & 11 & 3.25 & 0.51 & 3.05 & 0.57 \\
\hline & & NO & 1249 & 3.2 & 0.38 & 2.75 & 0.66 \\
\hline & \multirow{2}{*}{ AMI } & Yes & 1 & 3.03 & . & 3.03 & . \\
\hline & & NO & 21 & 3.31 & 0.53 & 2.6 & 0.74 \\
\hline & \multirow{2}{*}{ ASI } & Yes & 5 & 3.68 & 0.68 & 3.6 & 0.38 \\
\hline & & NO & 257 & 3.32 & 0.43 & 3.04 & 0.62 \\
\hline & \multirow{2}{*}{ HIS } & Yes & 5 & 3.17 & 0.2 & 3.18 & 0.75 \\
\hline & & NO & 127 & 3.23 & 0.4 & 2.85 & 0.65 \\
\hline & \multirow{2}{*}{ WHI } & Yes & 50 & 3.44 & 0.45 & 3.33 & 0.66 \\
\hline & & NO & 1868 & 3.27 & 0.45 & 2.96 & 0.68 \\
\hline Summary & & & 6452 & 3.21 & 0.43 & 2.82 & 0.7 \\
\hline
\end{tabular}


Table 3 Logistic Regression Analysis of Four-Year Graduation

\begin{tabular}{|c|c|c|c|c|c|c|c|c|c|}
\hline Parameter & & $\beta$ & $S E \beta$ & Wald's $\chi^{2}$ & DF & $p$ & $\begin{array}{l}e^{\beta} \\
\text { (odds } \\
\text { ratio) }\end{array}$ & $\begin{array}{l}95 \% \\
\text { confider } \\
\text { limits of }\end{array}$ & $\begin{array}{l}\text { Wald } \\
\text { nce } \\
\mathrm{fe}^{\beta}\end{array}$ \\
\hline Intercept & & -7.181 & 0.301 & 571.255 & 1 & $<.0001$ & NA & & \\
\hline High School GPA & & 0.426 & 0.077 & 30.565 & 1 & $<.0001$ & 1.531 & 1.316 & 1.780 \\
\hline $\begin{array}{l}\text { First-Year GPA } \\
\text { Gender }\end{array}$ & Female vs Male & $\begin{array}{l}1.580 \\
0.238\end{array}$ & $\begin{array}{l}0.069 \\
0.032\end{array}$ & $\begin{array}{l}528.707 \\
54.037\end{array}$ & $\begin{array}{l}1 \\
1\end{array}$ & $\begin{array}{l}<.0001 \\
<.0001\end{array}$ & $\begin{array}{l}4.853 \\
1.610\end{array}$ & $\begin{array}{l}4.242 \\
1.418\end{array}$ & $\begin{array}{l}5.553 \\
1.828\end{array}$ \\
\hline Race & AMI vs WHI & -0.731 & 0.435 & 2.825 & 1 & 0.093 & 0.405 & 0.146 & 1.124 \\
\hline Race & ASI vs WHI & -0.053 & 0.134 & 0.157 & 1 & 0.692 & 0.798 & 0.631 & 1.009 \\
\hline Race & BLK vs WHI & 0.422 & 0.109 & 14.974 & 1 & 0.000 & 1.282 & 1.113 & 1.477 \\
\hline Race & $\begin{array}{l}\text { HIS vs WHI } \\
\text { Unknown vs }\end{array}$ & 0.161 & 0.170 & 0.899 & 1 & 0.343 & 0.988 & 0.701 & 1.391 \\
\hline Race & WHI & 0.029 & 0.164 & 0.032 & 1 & 0.859 & 0.866 & 0.625 & 1.201 \\
\hline Study Abroad & Yes vs No & 0.095 & 0.109 & 0.761 & 1 & 0.383 & 1.208 & 0.790 & 1.849 \\
\hline
\end{tabular}

\begin{tabular}{llll} 
Test & $\chi^{2}$ & DF & $p$ \\
\hline Overall model & & & \\
evaluation & & & \\
Likelihood Ratio & 1196.796 & 9 & $<.0001$ \\
Score & 981.928 & 9 & $<.0001$ \\
Wald & 872.182 & 9 & $<.0001$ \\
Goodness-of-fit test & & & \\
\hline Hosmer and & & & \\
Lemeshow & 11.620 & 8 & 0.169 \\
\hline
\end{tabular}


Table 4 Logistic Regression Analysis of Five-Year Graduation

\begin{tabular}{|c|c|c|c|c|c|c|c|c|c|}
\hline Parameter & & $\beta$ & $S E \beta$ & Wald's $\chi^{2}$ & DF & $p$ & $\begin{array}{l}\mathrm{e}^{\beta} \\
\text { (odds } \\
\text { ratio) }\end{array}$ & \multicolumn{2}{|c|}{$\begin{array}{l}\text { confidence } \\
\text { limits of } e^{\beta}\end{array}$} \\
\hline & & & 0.26 & & & & & & \\
\hline \multirow[t]{2}{*}{ Intercept } & & -4.883 & 9 & 330.657 & 1 & $<.0001$ & NA & & \\
\hline & & & 0.07 & & & & & 1.36 & 1.80 \\
\hline \multirow[t]{2}{*}{ High School GPA } & & 0.453 & 1 & 40.646 & 1 & $<.0001$ & 1.573 & 9 & 8 \\
\hline & & & 0.05 & & & & & 3.35 & 4.17 \\
\hline \multirow[t]{2}{*}{ First-Year GPA } & & 1.321 & 6 & 557.393 & 1 & $<.0001$ & 3.745 & 7 & 9 \\
\hline & & & 0.02 & & & & & 1.12 & 1.39 \\
\hline \multirow[t]{2}{*}{ Gender } & Female vs Male & 0.112 & 8 & 15.671 & 1 & $<.0001$ & 1.251 & 0 & 8 \\
\hline & & & 0.28 & & & & & 0.43 & 1.66 \\
\hline \multirow[t]{2}{*}{ Race } & AMI vs WHI & -0.094 & 6 & 0.108 & 1 & 0.742 & 0.850 & 5 & 1 \\
\hline & & & 0.10 & & & & & 0.77 & 1.17 \\
\hline \multirow[t]{2}{*}{ Race } & ASI vs WHI & 0.023 & 7 & 0.047 & 1 & 0.828 & 0.956 & 6 & 6 \\
\hline & & & 0.08 & & & & & 1.09 & 1.40 \\
\hline \multirow[t]{2}{*}{ Race } & BLK vs WHI & 0.284 & 2 & 12.155 & 1 & 0.001 & 1.241 & 3 & 9 \\
\hline & & & 0.14 & & & & & 0.58 & 1.07 \\
\hline \multirow[t]{2}{*}{ Race } & HIS vs WHI & -0.161 & 0 & 1.317 & 1 & 0.251 & 0.795 & 8 & 4 \\
\hline & Unknown & & 0.13 & & & & & 0.62 & 1.09 \\
\hline \multirow[t]{2}{*}{ Race } & WHI & -0.122 & 4 & 0.823 & 1 & 0.364 & 0.827 & 2 & 9 \\
\hline & & & 0.12 & & & & & 1.15 & 3.05 \\
\hline Study Abroad & Yes vs No & 0.315 & 5 & 6.397 & 1 & 0.011 & 1.877 & 2 & 9 \\
\hline Test & & & & $\chi^{2}$ & DF & $p$ & & & \\
\hline \multirow{2}{*}{\multicolumn{10}{|c|}{$\begin{array}{l}\text { Overall model } \\
\text { evaluation }\end{array}$}} \\
\hline & & & & & & & & & \\
\hline & & & & 1188.81 & & & & & \\
\hline \multirow[t]{2}{*}{ Likelihood Ratio } & & & & 6 & 9 & $<.0001$ & & & \\
\hline & & & & 1049.85 & & & & & \\
\hline Score & & & & 4 & 9 & $<.0001$ & & & \\
\hline Wald & & & & 873.490 & 9 & $<.0001$ & & & \\
\hline \multicolumn{10}{|l|}{ Goodness-of-fit test } \\
\hline Hosmer and Lemeshow & & & & 12.232 & 8 & 0.141 & & & \\
\hline
\end{tabular}




\begin{tabular}{|c|c|c|c|c|c|c|c|c|c|}
\hline Parameter & & $\beta$ & SE $\beta$ & Wald's $\chi^{2}$ & DF & $\mathrm{p}$ & $\begin{array}{l}\mathrm{e} \beta \\
\text { (odd } \\
\mathrm{s} \\
\text { ratio) }\end{array}$ & $\begin{array}{l}95 \% \\
\text { confiden } \\
\text { limits of }\end{array}$ & $\begin{array}{l}\text { Wald } \\
\text { ce } \\
\text { e } \beta\end{array}$ \\
\hline & & & 0.27 & & & & & & \\
\hline Intercept & & -4.145 & $\begin{array}{l}9 \\
0.07\end{array}$ & 221.484 & 1 & $<.0001$ & $\begin{array}{l}\text { NA } \\
1.47\end{array}$ & & 1.70 \\
\hline High School GPA & & 0.390 & $\begin{array}{l}3 \\
0.05\end{array}$ & 28.547 & 1 & $<.0001$ & $\begin{array}{l}7 \\
3.63\end{array}$ & 1.280 & $\begin{array}{l}4 \\
4.05\end{array}$ \\
\hline First-Year GPA & & 1.291 & $\begin{array}{l}5 \\
0.02\end{array}$ & 549.474 & 1 & $<.0001$ & $\begin{array}{l}8 \\
1.22\end{array}$ & 3.265 & $\begin{array}{l}3 \\
1.37\end{array}$ \\
\hline Gender & Female vs Male & 0.103 & $\begin{array}{l}9 \\
0.28\end{array}$ & 12.765 & 1 & 0.000 & $\begin{array}{l}8 \\
0.87\end{array}$ & 1.097 & $\begin{array}{l}5 \\
1.69\end{array}$ \\
\hline Race & AMI vs WHI & -0.067 & $\begin{array}{l}1 \\
0.10\end{array}$ & 0.056 & 1 & 0.813 & $\begin{array}{l}4 \\
0.92\end{array}$ & 0.452 & $\begin{array}{l}0 \\
1.14\end{array}$ \\
\hline Race & ASI vs WHI & -0.008 & $\begin{array}{l}8 \\
0.08\end{array}$ & 0.005 & 1 & 0.943 & $\begin{array}{l}7 \\
1.17\end{array}$ & 0.750 & $\begin{array}{l}6 \\
1.34\end{array}$ \\
\hline Race & BLK vs WHI & 0.232 & $\begin{array}{l}1 \\
0.14\end{array}$ & 8.121 & 1 & 0.004 & $\begin{array}{l}9 \\
0.81\end{array}$ & 1.035 & $\begin{array}{l}1 \\
1.09\end{array}$ \\
\hline Race & $\begin{array}{l}\text { HIS vs WHI } \\
\text { Unknown vs }\end{array}$ & -0.139 & $\begin{array}{l}0 \\
0.13\end{array}$ & 0.991 & 1 & 0.320 & $\begin{array}{l}3 \\
0.85\end{array}$ & 0.601 & $\begin{array}{l}9 \\
1.14\end{array}$ \\
\hline Race & WHI & -0.087 & $\begin{array}{l}4 \\
0.14\end{array}$ & 0.415 & 1 & 0.519 & $\begin{array}{l}7 \\
2.03\end{array}$ & 0.643 & $\begin{array}{l}1 \\
3.52\end{array}$ \\
\hline Study Abroad & Yes vs No & 0.354 & 1 & 6.328 & 1 & 0.012 & 0 & 1.169 & 5 \\
\hline Test & & & & $\chi^{2}$ & DF & $p$ & & & \\
\hline $\begin{array}{ll}\text { Overall } & \text { model } \\
\text { evaluation } & \end{array}$ & & & & & & & & & \\
\hline Likelihood Ratio & & & & $\begin{array}{l}1114.31 \\
7 \\
1016.60\end{array}$ & 9 & $<.0001$ & & & \\
\hline Score & & & & 7 & 9 & $<.0001$ & & & \\
\hline Wald & & & & 816.931 & 9 & $<.0001$ & & & \\
\hline Goodness-of-fit test & & & & & & & & & \\
\hline Hosmer and Lemeshow & & & & 10.463 & 8 & 0.234 & & & \\
\hline
\end{tabular}

